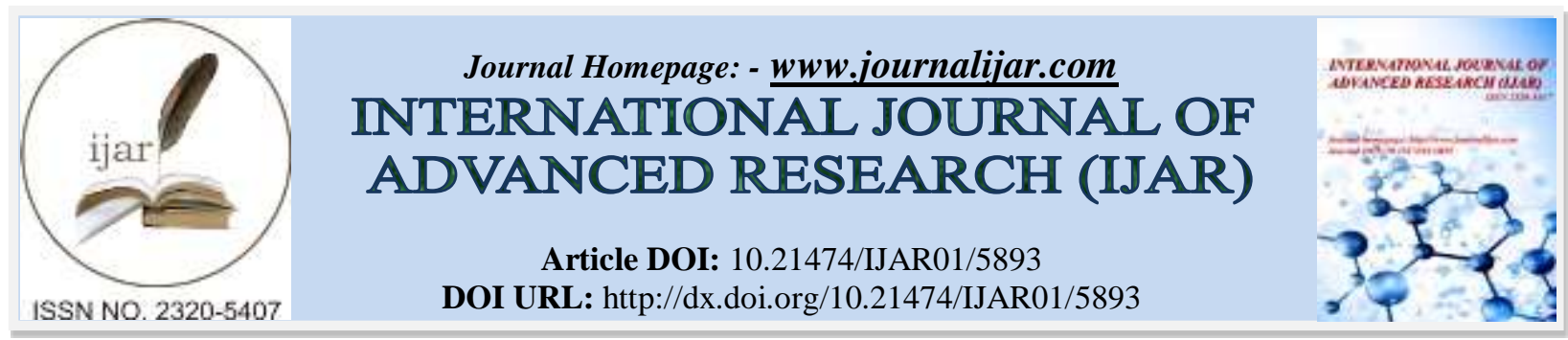

RESEARCH ARTICLE

\title{
THE EFFECT OF PACKAGING DESIGN, DISTRIBUTION CHANNEL EXPANSION AND WORK EXPERIENCE TOWARD THE INCOME LEVEL OF SUGAR PALM FARMERS IN WEST BANDUNG REGENCY, JAVA PROVINCE.
}

\author{
Sunarta $^{1}$ and Eti Rochaety ${ }^{2}$. \\ 1. Faculty of Economics and Business, University of Muhammadiyah. \\ 2. Prof. Dr. Hamka jakarta, Indonesia .
}

Manuscript Info
Manuscript History
Received: 17 September 2017
Final Accepted: 19 October 2017
Published: November 2017
Key words:-
Packaging Design, Distribution Channel,
Work Experience, Farmer's Income.

Packaging Design, Distribution Channe
Work Experience, Farmer's Income.

\begin{abstract}
The study aims to explain the effect of packaging design, expansion of distribution channels and work experience on the sugar palm farmers' income in West Bandung regency, West Java province. The survey research of descriptive quantitative was employed as to describe qualitative data. For primary data, interview was conducted to obtain information from craft men and traders. For secondary data, the researcher got the information from Department of Industry and Commerce, the Agriculture service, the Central Bureau of Statistics, Small and Medium Enterprise service of West Bandung regency and literature review. Multiple regression analysis was used to analyze data. The results have revealed that the design of the packaging, distribution channels and farming experience have positive effect on farmers' income. In conclusion, the sugar palm farmers need to develop more attractive packaging designs, and expand the distribution channels. In addition, their farming experience can be a valuable asset and capital to keep improving the capacities and capabilities in order that sugar palm farming business becomes the farmers' income resource, particularly and people of West Bandung, generally.
\end{abstract}

Copy Right, IJAR, 2017,. All rights reserved.

\section{Introduction:-}

The agricultural sector has an essential role in the national economy. Not only does it have a strategic position in increasing public income. But it also absorbs labor, which other economic sectors can't. For instance, during economic crisis occurring in 1998, the agricultural sector could survive and grow positively as well as absorb labor from other sectors as a result of reducing the risk of declining overall economic growth (Yudhoyono, 2004).

The agricultural sector is divided into various subsectors which are grouped based on the types of crops namely food crop sub-sector, horticulture crop sub-sector, and plantation sub-sector (Pahan, 2008). One of the plantation crops is areca palm tree or palm sugar (Arenga Pinnata) as one of the plantation commodities that have high economic value since almost all parts of this plant have a sale value and bring financial profits. Kolangkaling (the fuit of the sugar palm), which is favored by the community particularly during fasting month, has increasing sale for the farmers and traders. Its leaves become raw materials for handicrafts and rooftops. The roots can be used as remedy, and the stem can be used as fibers and stick (used for brooms). And for the old plants, they can be used as material for furniture 
while the sago can be taken from the young plants. Nevertheless, of all mentioned, only juice of the sugar palm has the highest economic value (Bank Indonesia, 2009), $70 \%$ of Indonesians live in rural areas and $46 \%$ of them depend on agriculture sector (the Central Bureau of Statistics, 2010). In regional, the effort to develop an agriculture based small industry is one of the ways to be implemented by local governments to minimize the amount of unemployment. The development of agro-industry as a continuation sub-sector of the agricultural sector will increase the added value and in turn it will be able to increase farmers' income, increase employment and improve rural development in general (Arumsari \& Syamsiar 2011).

Sugar palm making is one of the people's jobs, which is the dominant expertise and hereditary job in West Bandung regency. West Bandung regency is one region of the West Java province encompassing four sub districts as quite large sugar palm production centers, namely Sindangkerta, Saguling, Gunung Halu and Cipongkor. Such industry is classified as a traditional industry managed by the family for generations. Sugar palm producers are quite numerous in the four sub-districts covering about 167 craftsmen (16\%) of 1.073 total populations and divided into 12 villages, which their main livelihood is sugar palm making and farming.

The general marketing constraints of sugar palm product faced by craftmen are following:

1. Lack of knowledge regarding the sugar palm of the packaging design, product attributes (nutritional composition and benefit content), resulting in lower consumer appeal in a supermarket and hypermart

2. Lack of access to market information, especially about the price, which makes the craftsmen highly dependent on the price given by the collector (low bargaining position).

3. People are still less familiar with the products of sugar palm ants (product variations) as a substitute of sugar cane. Because of this less unfamiliarity, the sugar palm ant is better known for industrial purposes rather than for consumption. As a matter of fact, the opportunity to meet the needs of the sweetener market for market consumption is relatively large (Bank Indonesia, 2009).

Based on observations in West Bandung regency, since sugar palm plants grow naturally, there is no farmers' treatment to the plants. Likewise with the business of sugar palm making, it is still very traditional with the very minimal or simple use of technology. It even tends as the side job as for palm tapping performed twice a day in the morning and in the afternoon. The rest of their time is used for other farming activities. Sugar palm tapping is performed individually by each farmer, which then cooking process is done in the afternoon around the land of intercepted palm. Most of sugar palm businesses in West Bandung regency are a legacy from generation to generation. They manage the plants to take its juice of sugar palm, which then is processed into sugar palm. In some places, there are also farmers who sell juice to serve traditional drinks. In this study the factors affecting farmers' income, its traditional process, hereditary jobs, and as well as whether the sugar palm farming is beneficial in increasing the income and welfare of farmers will be discussed.

The development of sugar palm agroindustry faces similar obstacles to the development of other agro-industries such as: (1) Limited capital due to the very weak access of farmers to financing sources; (2) low quality of human resources as managers in the application of technology; (3) social and economic institutions which is far from the life of the community, (4) the government's disproportionate policies, inadequate development of facilities and infrastructure, unrooted programs from the problems faced by rural communities and unsustainable programs.

\section{Problem formulation:-}

1. How are the characteristics of sugar palm's craftsmen in terms of the level of business scale?

2. How is the packaging of sugar palm used by craftsmen in West Bandung regency?

3. How is the experience description of sugar palm's craftsmen in West Bandung regency?

4. How is the network of distribution channel ranging from craftsman level up to the last user in West Bandung regency?

5. Do the packaging and distribution channel have positive effect on the income level of craftmen in West Bandung regency?

\section{Literature review:- \\ Income:-}

Income is all incomes received by farmers derived from net profit in making sugar palm which is deducted by the cost of production and multiplied by the number of days a month in units of rupiah (Sihol Situngkir, 2007). Revenue for a number of economic actors is the money that has been received by the customers of the company as a result of 
the sale of goods and services. Revenue is also interpreted as the amount of income both of individuals and families in the form of money earned from the service every month, or it can also be interpreted as a success of the business (Tohar, 2000). The concept of income calculation can be implemented through three approaches as follows:

1. Production approach is to calculate the entire added value production of goods or services produced within a certain time measure.

2. Income approach is to count all the values of remuneration received by the owners of production factors in the size of a particular time.

3. Expenditure approach is to calculate all expenditures in a certain period of time. (Sukirno, 2004: 37)

\section{Packaging:-}

Packaging is a marketing and communication tool for the company's products, permanent sales media and available everywhere (Natadjaja, 2003: 127). Kotler (2014) defines packaging as "all the activities of designing and producing the container for a product." Packaging can be defined as the wrapping material around a consumer item that serves to contain, identify, describe, protect, display, promote, and otherwise make the product marketable and keep it clean. Packaging is the outer wrapping of a product. It is the intended purpose of the packaging to make a product readily sellable as well as to protect it against damage and prevent it from deterioration while storing. It can be concluded that the packaging is a common activity in the product planning through design or creation determination that serves as a protective packaging product and marketing communications tool. Three types of packaging measure used by sugar palm farmers are banana leather packaging, palm leaf packaging and simple plastic packaging.

\section{Distribution channel:-}

Distribution channel is product availability and easiness of obtaining the product. Distribution channel can be measured from (a) The easiness of getting products; (b) Location of purchase; (c) easy access location (Suryadi and Hutomo, 2010). According to Philip Kotler (2014:122) "Distribution channels are interdependent organizations included in the process that creates a product or service for use or consumption." Thus, it is inferred that the distribution channel is a marketing agency whose task is to distribute the product both to the industrial consumer and last consumers based on the determined company's management. A distribution channel is a group of merchants and agents combining physical displacement and the name of a product to create usefulness for a particular market. The size of the distribution of sugar palm by farmers is measured through two types of channels; collectors and retailers.

\section{Work experience:-}

Work experience determines the skill in performing a certain task. Work experience can have a positive or negative impact on one's ability (Fadiah, 2008). One's work experience shows the types of work that has been done and provides great opportunities to do a better job. The wider the work experience of a person is, the more skilled the person is in doing the work and the more perfect of his/her pattern of thinking and attitude to achieve the determined goals (Abriyani Puspaningsih, 2004). In this context, the work experience of sugar palm farmers is measured from their length of time to become farmers. Below figure is the research framework.

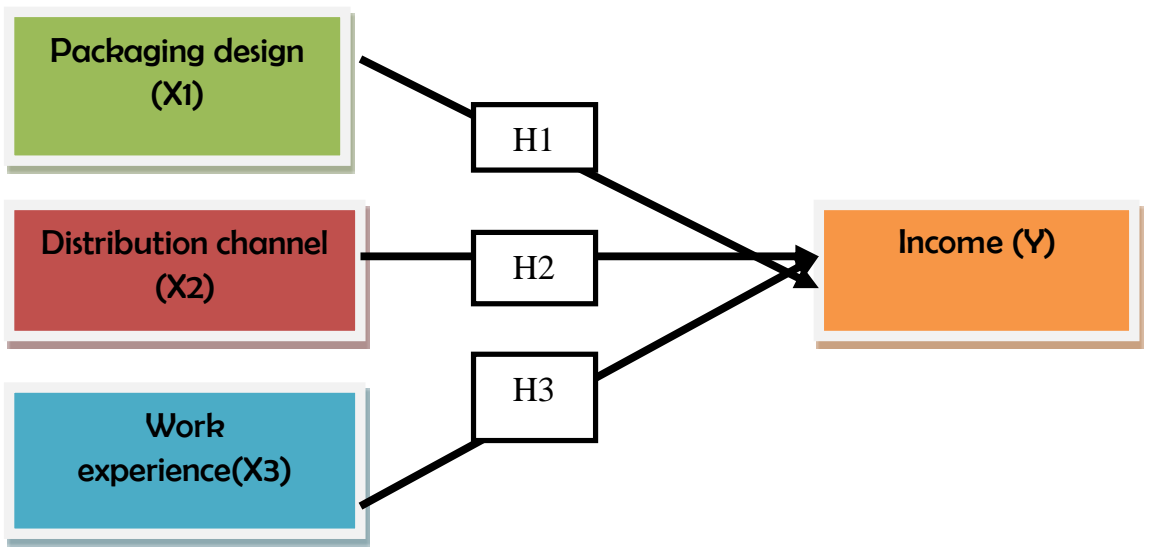

Figure 1:- Research Framework 


\section{Research Method:-}

This is a survey research of descriptive quantitative, which aims to describe qualitative data and test the contributions among variables from proposed hypothesis, which is then validated with empiric data (Eti: 2009). 167 sugar palm craftsmen were taken as total population in 4 sub districts and 12 villages of West Bandung regency. Since saturated sample or census was used as sampling method, all members of the population become the sample of the research. Besides, this method was used because sugar palm craftmen only spread across four sub districts. The data in this study consisted of primary data and secondary data. For primary data, interview was conducted to obtain information from craft men and traders by using interview guide/protocol. For secondary data, the researcher got the information from Department of Industry and Commerce, the Agriculture service, the Central Bureau of Statistics, Small and Medium Enterprise service of West Bandung regency and literature review and library research as well. A library research is a study to collect and analyze secondary data in the form of books, documents, reports, studies, journals and other literature. For data analysis, multiple regression analysis was used.

\section{Results and Discussion:-}

\section{General description:-}

West Bandung regency is one area situated in West Java consisting of 16 (sixteen) sub districts: Padalarang, Cikalongwetan, Cililin, Parongpong, Cipatat, Cisarua, Batujajar, Ngamprah, Gununghalu, Cipongkor, Cipeundeuy, Lembang, Sindangkerta, Cihampelas, Rongga and Saguling. In terms of land use, 66.500.294 hectares are used for agricultural cultivation as the largest land use, while 50.150.928 hectares are the protected forest area, 12.159.151 hectares are non-agricultural cultivation area, and 1.768.654 hectares are for the other uses. However, based on the views of the physical condition, the geographical position of West Bandung regency is considered less favorable due to many hilly basins and vulnerable areas to natural disasters in certain areas

Table 1:- The number of sugar palm craftmen in sub districts

\begin{tabular}{|l|l|l|}
\hline No & Sub district & The number of craftmen \\
\hline 1 & Cipongkor & 36 \\
\hline 2 & Gunung Halu & 46 \\
\hline 3 & Saguling & 47 \\
\hline 4 & Sindangkerta & 39 \\
\hline & Total number & $\mathbf{1 6 7}$ \\
\hline
\end{tabular}

\section{Source: Research Findings in 2016}

Table 2:- Sugar palm Farmers' Income (Average / day)

\begin{tabular}{|c|c|c|c|}
\hline No & $\begin{array}{l}\text { The average income / day } \\
\text { (IDR) }\end{array}$ & $\begin{array}{l}\text { The number of } \\
\text { farmers (people) }\end{array}$ & Percentage (\%) \\
\hline 1 & 60.000 & 12 & 7.18 \\
\hline 2 & 114.000 & 17 & 10.18 \\
\hline 3 & 156.000 & 50 & 29.94 \\
\hline 4 & 267.000 & 57 & 34.15 \\
\hline 5 & 171.000 & 21 & 12.57 \\
\hline 6 & 100.000 & 10 & 5.98 \\
\hline & Total number & 167 & 100.00 \\
\hline
\end{tabular}

Source: Research Findings 


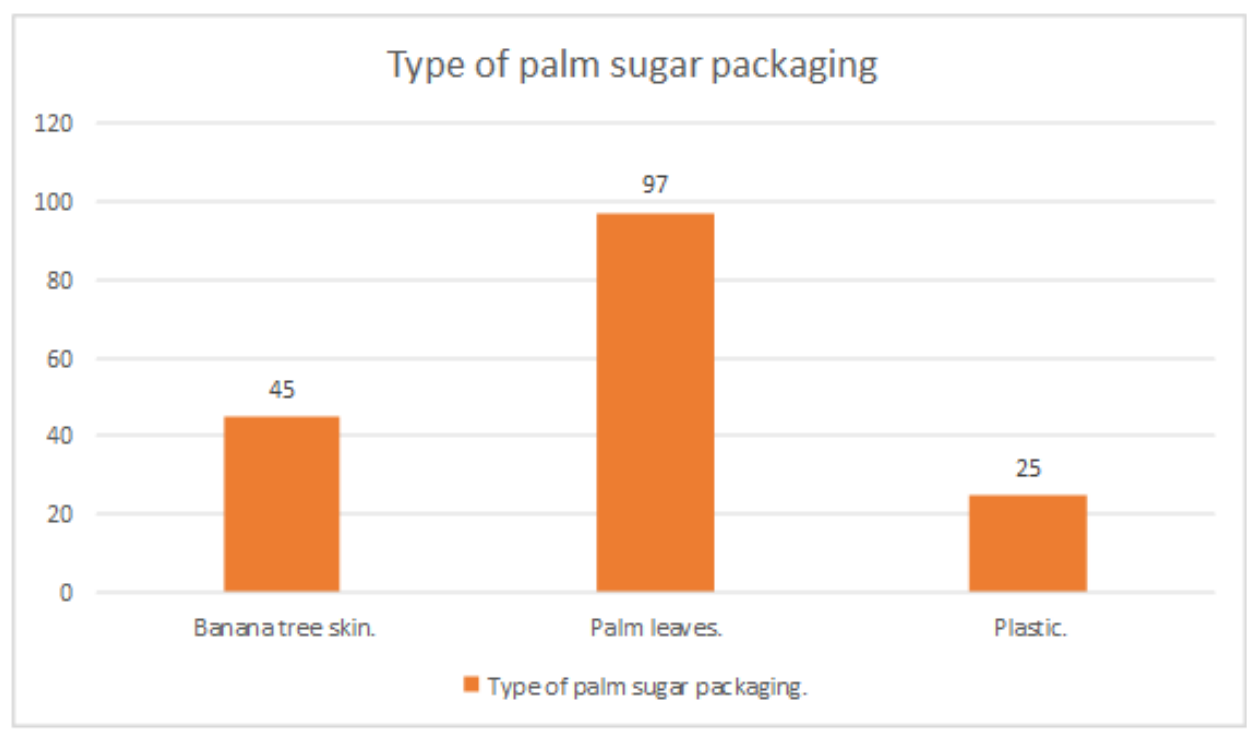

Figure 1:- Sugar Palm Packaging Type

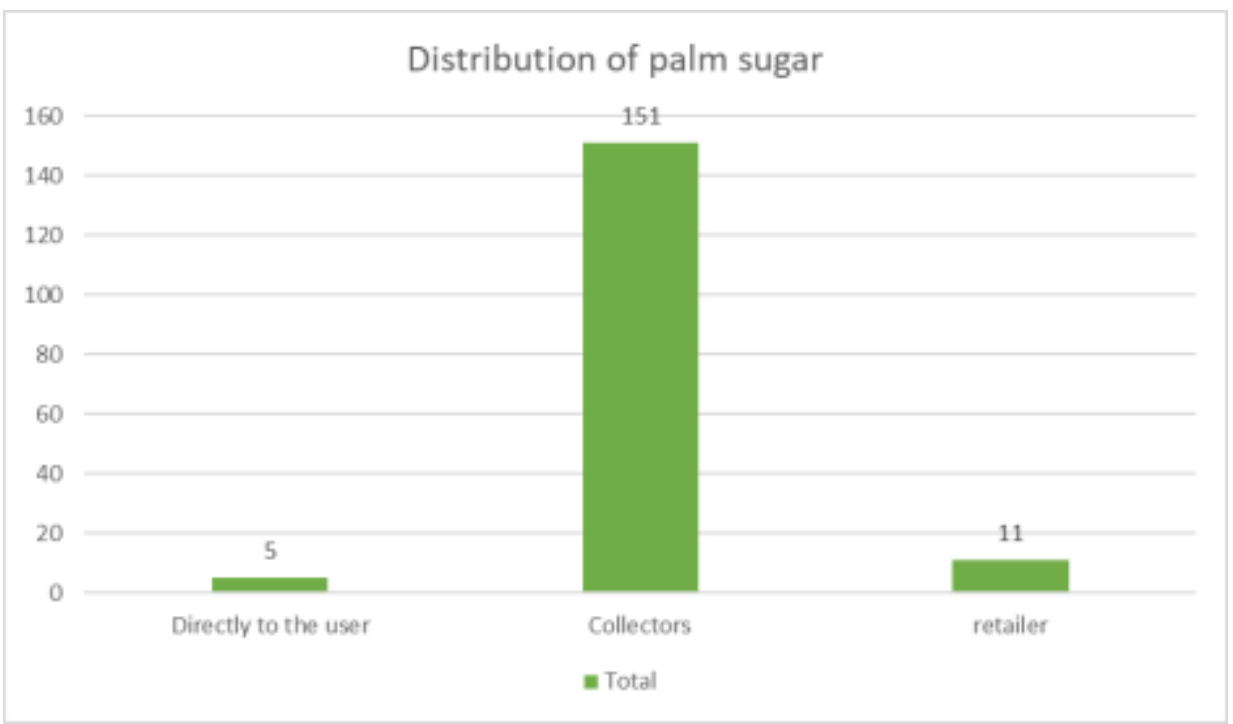

Figure 2:- Distribution of Sugar palm 


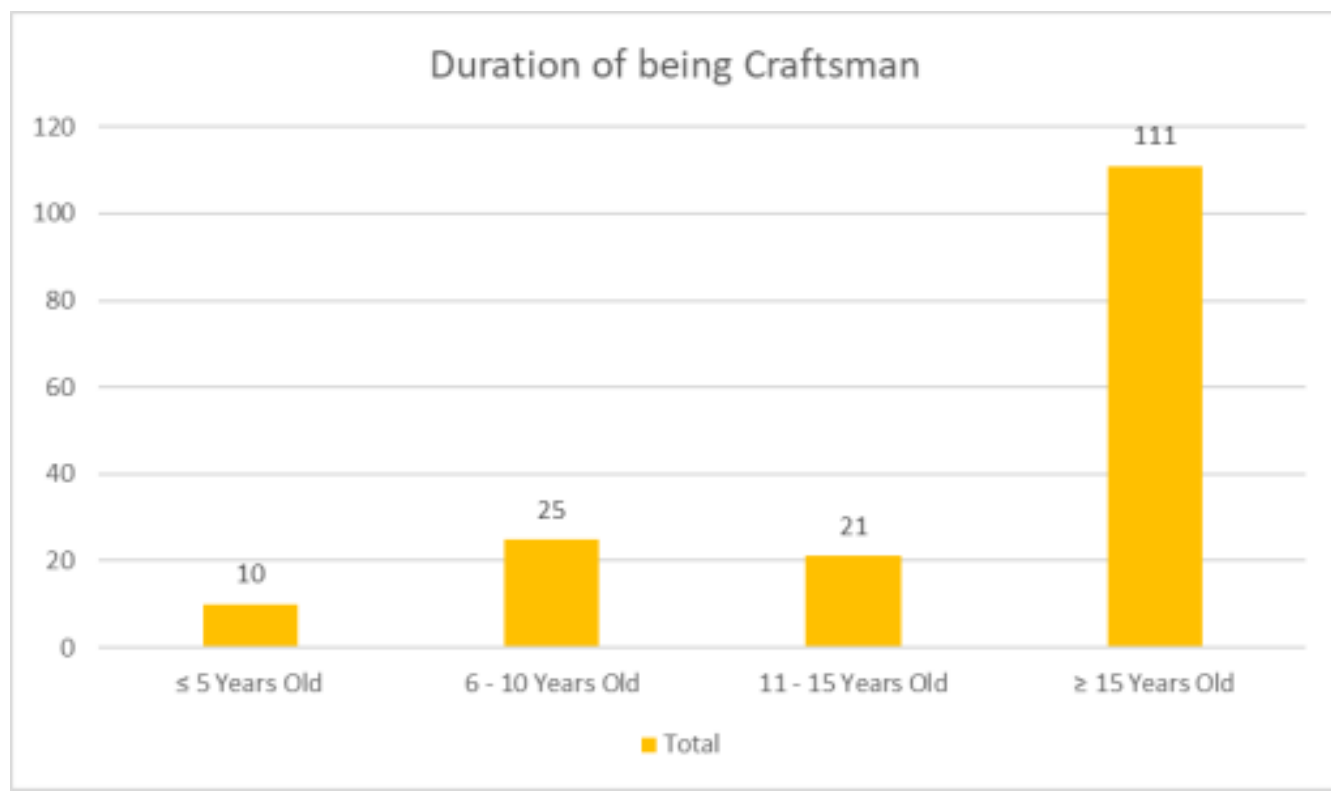

Figure 3:- Respondents’ Work Experience

The results of Multiple Linear Regression Analysis:-

Here is the description of the dependent variable (respondents' income) and the independent variables (work experience, packaging design, and distribution channels) as well as its relationship. The effect of each variable was tested by multiple linear regressions summarized in the following table:

Table 5:- Regression Analysis

\begin{tabular}{|c|c|c|c|c|c|c|}
\hline \multirow[t]{2}{*}{ Model } & \multicolumn{2}{|c|}{ Coefficients unstandardized } & \multirow{2}{*}{$\begin{array}{l}\text { Standardized } \\
\text { Coefficients } \\
\text { beta }\end{array}$} & \multirow[t]{2}{*}{ T-Value } & \multirow[t]{2}{*}{ T-Table } & \multirow[t]{2}{*}{ Sig. } \\
\hline & B & Std. Error & & & & \\
\hline (Constant) & 46607.20 & 10130.36 & & 4601 & \multirow{4}{*}{1,654} & .000 \\
\hline Experience & 7685.46 & 2390.14 & .191 & 3,215 & & .002 \\
\hline Packaging & 53294.27 & 3827.13 & .889 & 13925 & & .000 \\
\hline Distribution & 26254.89 & 5430.69 & .212 & 4835 & & .000 \\
\hline \multicolumn{4}{|c|}{$\begin{array}{l}\text { Multiple Correlation (R) } \\
\text { Coef. Determination (R2) } \\
\text { F-test } \\
\text { F-table } \\
\text { Probability }\end{array}$} & \multicolumn{3}{|l|}{$\begin{array}{l}0877 \\
0770 \\
181.72 \\
2.66 \\
0000\end{array}$} \\
\hline
\end{tabular}

Correlation (r) of 0.88 indicates that there is a strong correlation between the variables $\mathrm{X}_{1}, \mathrm{X}_{2}$, and $\mathrm{X}_{3}$ simultaneously with $\mathrm{Y}$ of 0.88 . The coefficient of determination (R2) was $\mathrm{R}=0.77$, which means the design of the packaging, distribution channels and farming experience as independent variables were able to explain the variation in the dependent variable, that is revenues by $88 \%$ while the remaining $12 \%$ is explained by other variables excluded in the model.

$Y=46607.20+7685.46 \mathrm{X} 1+53294.27 \mathrm{X} 2+26254.89 \times 3$

From the above equation, it can be interpreted that: Intercept (bo) 46607.20 mathematically means if the design of the packaging, distribution channels and farming experience is 0 , then $\mathrm{Y}$ or the average revenue of respondent per day is an increase of IDR 46607.20 per day.

The effect of Packaging Design $\left(\mathrm{X}_{1}\right)$ on Income of sugar palm farmers $(\mathrm{Y})$ :-

1. 7685.46 packaging design means one times of every change of packaging design with the price assumption, soak, and total fixed number of tapped trunk will raise Y or revenue of IDR 7685.46 / day. 
2. Based on the T-test partially, it can be seen that coefficient $X_{1}$ (Packaging Design) has partially positive effect on income (Y) at the $\alpha(0.05)$ so that Ho: rejected and $\mathrm{H}_{1}$ : accepted (variable $\mathrm{X}_{1}$ has a significant effect on $\mathrm{Y}$ ).

3. Based on the obtained values of packaging design, packaging design will give considerable effect on the sugar palm farmers' income in West Bandung regency in the amount of IDR 7685.46 / day.

4. The efforts conducted to develop packaging by farmers in West Bandung regency are: (1) Promoting the sugar palm packaging to more modern plastic pouch standing models adjusted to the size of the sugar palm produced; (2) Promoting nutrition sugar palm testing at authorized institutions such as Sucofindo, Indonesian national agency of drug and food control and Halal label to strengthen consumer trust to the quality and legality of Sugar Palm as worth consuming food.

The effect of Distribution Channels $\left(\mathrm{X}_{2}\right)$ on Income of sugar palm farmers $(\mathrm{Y})$ :-

1. 53294.27 distribution channel means any expansion of distribution channels by one time with the packaging design assumptions and fixed farming experience will increase Y or revenues of IDR 53294.27 / day.

2. Based on the T-test partially, it can be seen that coefficient $X_{2}$ (distribution channel) has partially positive effect on income (Y) at the $\alpha(0.05)$ so that Ho: rejected and $\mathrm{H} 1$ : accepted (variable $\mathrm{X}_{2}$ has a significant effect on $\mathrm{Y}$ ).

3. Based on the obtained values of distribution channel, distribution channel will give a considerable effect on the sugar palm farmers' income in West Bandung regency of IDR 53294.27 / day.

4. The Efforts done by palm sugar farmers to expand distribution channels are: (1) Promoting the marketing network in groups through retailers; (2) Following the mentoring conducted by the higher education as a part of community service activities by expanding the marketing network outside the territory of West Bandung regency.

The effect of farming work experience $\left(\mathbf{X}_{3}\right)$ on Income of sugar palm farmers $(\mathbf{Y})$ :-

1. 26254.89 farming work experience means that each additional year of experience with the packaging design assumptions and fixed distribution channels will increase Y or revenues of IDR 26254.89 / day.

2. Based on the T-test partially, it can be seen that coefficient $X_{3}$ (work experience) has partially positive effect on income (Y) at the $\alpha(0.05)$ so that Ho: rejected and $\mathrm{H}_{1}$ : accepted (variable $\mathrm{X}_{3}$ has a significant effect on $\mathrm{Y}$ ).

3. Based on the gained value of farming work experience, work experience will give a considerable influence on the sugar palm farmers' income in West Bandung regency of IDR 26254.89 / day.

4. Farmers' efforts to develop skills of their work experience are: (1) Promoting the improvement of knowledge and skills through training in collaboration with various agencies, so that farmers understand that sugar palm has market more appeal, if managed more modernly (2) Farmers are given an understanding of the manufacturing variations of sugar palm, that is sugar palm ants that have higher prices, as the market for sugar palm ants are business institutions such as hotels, hospitals, cafes and so on.

\section{Conclusion:-}

1. Based on the results of regression analysis, packaging design has a significant effect on the income level of sugar palm farmers in West Bandung regency. Thus, the change of sugar palm packaging is one of the best ways to increase the income of sugar palm farmers.

2. The expansion of distribution channel becomes a requirement for sugar palm farmers in West Bandung regency. Because the result of regression analysis shows that the expansion of distribution channel, besides through collector, can increase the income of sugar palm farmers in West Bandung regency.

3. Due to the farmers' experiences, they are not only able to survive as sugar palm farmers, but they can make farming as a promising generating income. It is shown from the results that the work experience has a significant effect on earnings.

\section{References:-}

1. Arsyad, Lincolin. 2005. Pengantar Perencanaan dan Pembangunan Ekonomi. Daerah. Second edition. Yogyakarta:BPFE

2. Backer.M; \& Sharen.M. 2010. Marketing Theory; A Student Text. Second Edition. Los Angeles: Sage Publication

3. Batubara; Rujiman; \& Rahmanta. 2014. Analisis faktor-faktor yang mempengaruhi pendapatan petani gula aren dan pengembangannya pada lahan marginal di kabupaten Tapanuli Selatan, Jurnal Ekonomi. Vol.17.No.4.h. 162 - 173. Retrieved on 20 April 2017 
4. Rochaety, Eti., et al. 2009. Metodologi Penelitian Bisnis dengan Aplikasi SPSS. Revision edition. Jakarta: Mitra Wacana Media.

5. Geoff Lancaster and Lester Massingham. 2011. Essentials of Marketing Management. New York: Routledge Taylor and Francis Group.

6. Kaunang, Jeane D.,W. Uguy, Ch. Ngangi, MS (2010) Strategi Pemasaran Industri Rumah Tangga Gula Aren di Kota Tomohon Sulawesi Utara.

7. Kotler.P \& Armstrong.G. 2014. Principles of Marketing. 14 ${ }^{\text {th }}$. New York: Pearson Prentice Hall.

8. Kotler.P \& Keller.K.L. 2014. Marketing Management. $15^{\text {th }}$. New York Prentice Hall

9. Munir, Risfan, \& Bahtiar Fitanto 2005. Pengembangan Ekonomi Lokal Partisipatif: Masalah, Kebijakan, Dan Panduan Pelaksanaan Kegiatan.

10. Peraturan Menteri Negara Badan Usaha Milik Negara Nomor PER-05/MBU/2007 Tentang Program Kemitraan Badan Usaha Milik Negara dengan Usaha Kecil dan Program Bina Lingkungan.

11. Sukirno, Sadono. 2002. Pengantar Ekonomi Mikro. Yogyakarta: BPFE.

12. Susila, W.R. 2006. Dinamika Impor Gula Indonesia: Sebuah Analisis Kebijakan.http://www.ipard.com/art_perkebun/Nov07-06_wr.asp. (Diakses18 Nopember 2016)

13. Suyitno. 2017. Quality of Health Service And Its Effect On Patient Satisfaction In Dr. Syaiful Anwar Hospital Of Malang Indonesia, International Journal Of Advanced Research (IJAR) Vol.5.No.3. p.480-488.

14. Undang-Undang Republik Indonesia Nomor 20 Tahun 2008 tentang Usaha Mikro, Kecil, dan Menengah

15. http://metrotvnews.com/read/newsvideo/2011/02/22/122938/PeluangEksporGulaMerahTerbuka Lebar Peluang Ekspor Gula Merah Tebu Terbuka Lebar. Retrieved on 10 Desember 2016

16. http://www.javasugar.com/gula.htm. Ganti Pemanis Anda dengan Gula Jawa. Retrieved on 18 Februari 2017)

17. http://www.lensaindonesia.com/2012/01/24/permintaangulamerahmeningkatrafinasijadialternatif2.html. (Diakses 18 Februari 2017)

18. download.portalgaruda.org/article.php?article $=148069 \&$ val $=4918$ (Retrieved on 13 April 2017)

19. Repository.usu.ac.id/bitstream/123456789/.../manajemen-syahyunan7.pd. (Retrieved on 8 April 2017)

20. Repository.usu.ac.id/bitstream/123456789/33753/4/Chapter\%20II.pdf (Retrieved on 3 Februari 2017)

21. Eprints.uny.ac.id/7732/3/BAB\%202-06408144012.pdf (Retrieved on 15 Januari 2017)

22. Repository.widyatama.ac.id/bitstream/handle/10364/.../content\%201.pdf? (Retrieved on 6 September 2016)

23. Repository.widyatama.ac.id/xmlui/bitstream/handle/.../Bab\%202.pdf? (Retrieved on 2 Oktober 2016) 